\title{
Study on Estimating Methods of Evapotranspiration in Cold and Arid Region
}

\author{
Jiabin $\mathrm{Wu}^{1,2, \mathrm{a}}$, Shu Miao ${ }^{2, \mathrm{~b}}$ Xiaofeng $\mathrm{Du}^{2, \mathrm{c}} \mathrm{Na}$ Zhang ${ }^{3, \mathrm{~d}}$ \\ ${ }^{1}$ Inner Mongolia University, Hohhot, China \\ ${ }^{2}$ Institute of Water Resource for Pastoral Area, Hohhot, China \\ ${ }^{3}$ Inner Mongolia Agricultural University, Hohhot, China \\ amkswjb@163.com, ${ }^{b}$ miaoshu@vip.sina.com, ${ }^{c} d x f \_a b c @ 163 . c o m,{ }^{d} 71084$ \\ 0895@qq.com
}

\begin{abstract}
The estimate methods of evapotranspiration was studied in several methods including field measurement, instrument measurement and Penman - Monteith formula. There are slight differences between the results calculated by the 3 methods. As a traditional method, field measurement has high credibility. By the analysis of the results between field measurement and instrument measurement, the maximum stage error is more than $10 \%$, the minimum stage error is $2.7 \%$ and the average error is $3.11 \%$. This conclusion indicates that the instrument measurement called ENVIdata which is automatic measurement system have an acceptable accuracy to estimate evapotranspiration. The stage error is about $5 \%$ between the evapotranspiration results of Penman Monteith formula calculation and field measurement, the average error in whole growth period is $4.24 \%$. The result of Penman Monteith formula calculation is higher than the result of field measurement, analysis the causes of this phenomenon, the reason is that there is not any drought stress between the whole period as the background of formula calculation, but in fact drought stress may be occured during the irrigation intervals of surge irrigation.
\end{abstract}

Keywords: evapotranspiration, cold and arid region, estimate, methods. 


\section{Introduction}

Mu Us Sandland, located in the southern Ordos Plateau and northern Loess Plateau, border zone of Inner Mongolia, Shaanxi, and Ningxia, is arid and semi-arid transition zone, dry cold in winter, windy and dry in spring, warm and humid in summer, and shortly cool in autumn, with a total area of approximately 3.4 million hm2, it is also one of the five sandlands in China. Mu Us Sandyland is located in the middle of North Ecotone, with sensitive and fragile ecological environment. Mu Us Sandland's vegetation can be divided into three zones with the three major groups. From the vegetation zones, its western edge belongs to the sub-desert steppe zone with transition to desert, central and eastern regions, accounting for over $90 \%$, belong to steppes sub-zone. In the southeastern edge, it begins to transit to forest steppe, but because of Chaki coverage, differences in the vegetation are not significant, generally still is classified as steppe sub-zone. Three groups of vegetation in this area are grassland and shrub vegetation on the ground, semi-fixed and fixed sand dunes and sandy shrubs, and marsh, saline soil and meadow vegetation on the beach ground.

Test area is located in the abdomen of the Mu Us Sandland, Inner Mongolia Erdos City Wushenqi Mu Us Sandland Remediation Research and Development Center. Test area has four distinct seasons, serious drought, relatively concentrated rainfall, dry and cold in winter. The average temperature is about $6.8^{\circ} \mathrm{C}$, under extreme conditions, the maximum temperature is $36.5^{\circ} \mathrm{C}$, the lowest temperature is $-29^{\circ} \mathrm{C}$, rainfall is mainly concentrated in June-August, with annual rainfall between $350-400 \mathrm{~mm}$, strong evaporation, multi-year average evaporation of $2200-2800 \mathrm{~mm}$, and annual number of sunshine is 2886h. Frost-free period is 113-156d. Wushenqi has existing forage land irrigated area of 25.38 million mu, all for groundwater irrigation, in which water-saving irrigation area is 10.95 million mu, and main types of planting are forage corn silage and alfalfa.

\section{Estimate Methods of Evapotranspiration}

Field measurement. Basic theory used by field measurement method to estimate silage corn evapotranspiration is water balance method. Grass water supply and 
demand balance calculation is an important basis for lawn irrigation decisions. If the amount of water available for grass in a certain period cannot meet crop water demand, we need artificial irrigation as supplement, available water of area of grassland for a certain period of time is mainly composed of four parts of irrigation amount, effective rainfall, groundwater recharge and effective water storage of soil; lawn evapotranspiration is mainly grassland evapotranspiration and deep percolation. For grassland water cycle, from long-term natural process point of view, they are also in a continuous state of relative dynamic balance, the basic approach for studies of input and output, storage and conversion of grassland is water balance method. Physical meaning of water balance method is that input and output of grassland water within a certain period of time are equal. Thus, evapotranspiration of corn silage based on the water balance calculation can be written as the following equation.

$$
E T_{C}=I+P+G-\Delta W-D .
$$

Where, I refers to the amount of irrigation water, $\mathrm{P}$ refers to effective precipitation, $\mathrm{G}$ refers to groundwater rechange, $\mathrm{W}$ refers to soil water variation, $\mathrm{ET}_{\mathrm{c}}$ refers to the crop evapotranspiration, D refers to soil water leakage, units are $\mathrm{mm}$.

In field measurement method, irrigation amount, effective precipitation, soil water changes are measured, and groundwater recharge and soil water leakage are calculated on the basis of measurement of soil water potential and unsaturated hydraulic conductivity obtained in laboratory by using Darcy's equation, parameters on the right of equation (1) are obtained via estimates, and evapotranspiration of corn silage can be calculated by field measurement and based on the principle of water balance, the results are the table below.

Table 1 Evapotranspiration of silage maize measured by field test

\begin{tabular}{|c|c|c|c|c|c|}
\hline \multirow{2}{*}{ Growth stage } & \multicolumn{2}{|c|}{ Seedlin Jointin } & \multirow{2}{*}{$\begin{array}{l}\text { Heading and } \\
\text { flowering }\end{array}$} & \multirow{2}{*}{$\begin{array}{c}\text { matur } \\
\text { e }\end{array}$} & \multirow{2}{*}{$\begin{array}{c}\text { The whole growth } \\
\text { period }\end{array}$} \\
\hline & g & g & & & \\
\hline Evapotranspiration(mm) & 86.2 & 158.3 & 255.8 & 105.9 & 606.2 \\
\hline $\begin{array}{l}\text { Evapotranspirationintensity }(\mathrm{mm} / \\
\text { d) }\end{array}$ & 4.31 & 5.28 & 5.12 & 4.24 & 4.73 \\
\hline
\end{tabular}


Evapotranspiration of corn silage in whole growth period in Mu Us Sandland obtained via field measurement method estimates is $606.2 \mathrm{~mm}$, the average evapotranspiration intensity is $4.73 \mathrm{~mm} / \mathrm{d}$.

Instrument measurement. ENVIdata grass evapotranspiration automatic measurement system is a device capable of automatic turf evapotranspiration measurement, it can directly measure ET value of turf, crops, orchards and vineyards. Hidden ceramic evaporator at the top can simulate solar absorption and evapotranspiration resistance of crop irrigation. Infrared leaf surface temperature sensors can monitor plant leaf surface temperature in real time, air temperature and humidity sensor is equipped for monitoring of air temperature and humidity in field microclimate, and soil temperature and humidity sensor is used to monitor soil moisture conditions. In this study, ENVIdata grass evapotranspiration scattered force automatic measuring system is used to measure evapotranspiration of corn silage.

Table 2 Evapotranspiration of silage maize measured by instrument measurement method

\begin{tabular}{|c|c|c|c|c|c|}
\hline \multirow{2}{*}{ Growth stage } & \multicolumn{2}{|c|}{ Seedlin Jointin } & \multirow{2}{*}{$\begin{array}{l}\text { Heading and } \\
\text { flowering }\end{array}$} & \multirow{2}{*}{$\begin{array}{c}\text { matur } \\
\mathrm{e}\end{array}$} & \multirow{2}{*}{$\begin{array}{c}\text { The whole growth } \\
\text { period }\end{array}$} \\
\hline & g & g & & & \\
\hline Evapotranspiration(mm) & 75.75 & 152.5 & 248.9 & 112.5 & 589.7 \\
\hline $\begin{array}{l}\text { Evapotranspiration } \\
\text { intensity(mm/d) }\end{array}$ & 3.79 & 5.08 & 4.98 & 4.50 & 4.59 \\
\hline
\end{tabular}

Evapotranspiration of corn silage in whole growth period in Mu Us Sandland obtained via instrument measuring method is $589.7 \mathrm{~mm}$, the average evapotranspiration intensity is $4.59 \mathrm{~mm} / \mathrm{d}$.

Penman-Monteith formula calculation. In 1980, FAO redefined the reference crop water consumption, namely the evapotranspiration rate of hypothetical reference crop canopy, the height of the hypothetical crop is $0.12 \mathrm{~m}$, with fixed foliar resistance of $70 \mathrm{~s} / \mathrm{m}$, reflecting rate of 0.23 . It is equivalent to evapotranspiration of dry green grass with consistent height, vigorous growth, and completely covered ground. 
Based on meteorological data of the study area, we can calculate water consumption of corn silage according to the improved Penman Equation, the results are shown below.

Table 3 Evapotranspiration of silage maize calculated by Penman-Moteith formula

\begin{tabular}{|c|c|c|c|c|c|}
\hline \multirow{2}{*}{ Growth stage } & \multicolumn{2}{|c|}{ Seedlin Jointin } & \multirow{2}{*}{$\begin{array}{l}\text { Heading and } \\
\text { flowering }\end{array}$} & \multirow{2}{*}{$\begin{array}{c}\text { matur } \\
\mathrm{e}\end{array}$} & \multirow{2}{*}{$\begin{array}{c}\text { The whole growth } \\
\text { period }\end{array}$} \\
\hline & g & g & & & \\
\hline Evapotranspiration(mm) & 91.2 & 164.5 & 282.4 & 101.2 & 639.3 \\
\hline $\begin{array}{c}\text { Evapotranspiration } \\
\text { intensity(mm/d) }\end{array}$ & 4.56 & 5.48 & 5.65 & 4.05 & 4.94 \\
\hline
\end{tabular}

Evapotranspiration of corn silage in whole growth period in $\mathrm{Mu}$ Us Sandland obtained with improved Penman-Monteith formula is 639.3mm, the average evapotranspiration rate is $4.94 \mathrm{~mm} / \mathrm{d}$.

\section{Analysis and comparison of methods}

In this study, three kind of methods are used to calculate evapotranspiration of corn silage in Mu Us Sandland, namely field measurement method, instrument measuring, and improved Penman Formula.

The results of instrument measuring, compared with measured results of field measurement method, seedling period has the maximum error of over $10 \%$, other reproductive phases errors are about $5 \%$, while the whole growth period error is $3.11 \%$, indicating ENVIdata grass evapotranspiration automatic measuring system has a high accuracy, while the instrument measured value of corn silage evapotranspiration is lower than the actual. Error between calculation results of Penman-Monteith Formula and measured values in different growth stages of corn silage is about $5 \%$, in which error in ear and flowering period exceeds $10 \%$, the average error of whole growth period is $4.24 \%$, and calculated $\mathrm{f}$ corn silage Evapotranspiration is greater than the measured value, via analysis, the reasons is that this method of calculating takes the background that the crop is not dry, while corn silage in test area uses surge irrigation, in the irrigation interval, there 
may be some drought stress with the crop, resulting in differences in the calculation results.

\section{Summary}

Due to overgrazing and irrational reclamation, since the 1980s, Mu Us Sandland has increasing desertification, ecological environment continues to deteriorate. In recent years, with the strengthening of grassland ecological protection awareness, the water-saving irrigation forage in this region develops rapidly, especially acreage of high-yield forage crop - silage corn has significant increase, making contribution to the promotion of modernization and sustainable development of animal husbandry, increasing forage production and pastoralists income, and relieving grassland ecological pressure and conflict between water livestock supply and demand.

Mu Us Sandland's silage corn whole growing season is 125 days or so, average evapotranspiration intensity in the whole growth period is $4.73 \mathrm{~mm} / \mathrm{d}$, evapotranspiration is $606.2 \mathrm{~mm}$, of which evapotranspiration intensity in silage corn seedling, jointing, heading- flowering, maturity periods are $4.31 \mathrm{~mm} / \mathrm{d}$, $5.28 \mathrm{~mm} / \mathrm{d}, 5.12 \mathrm{~mm} / \mathrm{d}, 4.24 \mathrm{~mm} / \mathrm{d}$ or so.

Error between calculation results of ENVIdata grass evapotranspiration automatic measurement system and measured values in silage corn seedling period is $12.12 \%$, via analysis, the reason is greater volatility in climate change and large wind speed in the early growth period, and the average error in whole growth period is only $3.11 \%$, indicating the measuring system has a high degree of accuracy, the instrument measurement results are less than the crops water consumption in value. Average error between results of Penman-Monteith Formula and field measurement in water consumption is about 5\%, and calculated water consumption of silage corn is larger than measured value, the reason is that there are some differences in the calculation background of this method and the actual situation. 


\section{Acknowledgments}

This work has been funded by National natural science foundation of Chian (51309165), China ministry of water resources of public welfare sector specific research (201201008), “948” project of ministry of water resources(201202), China institute of water resource and hydropower research specific research(MK2014J05).

\section{References}

[1] Guo Kezhen, Li Hepin, Shi Haibin, et al. Study on Water Rate of Fodder Grass and Optimization of Saving Water Irrigation Program in Maowusu sandlot[J]. Journal of irrigation and drainage, 2006, Vol 24 (1) : 24-27.

[2] Qiu Xinqiang, Lu Zhenguang, Meng Chunhong, et al. Effects of Drought in Different Growth Stages on Evapotranspiration and Water Use Efficiency of Summer Maize[J]. Chinese Agriculture Science Bulletin, 2013, Vol 29 (27) : 68-75.

[3] Xu Minyun, Li Jianguo, Xie Fan, et al. Effect of different fertilizer applications on silage maize growth and hay output[J]. Acta Partaculturae Sinica, 2010, Vol 19 (3) : 245-250.

[4] Li Chunxi, Ye Runrong, Du Yangong, et al. Research on Production Performance of Silage Maize in Alpine Meadow Region[J]. Acta Agrestia Sinica, 2013, Vol 21 (6) : 1214-1217.

[5] Weishaar M A, Brummer E C, Volenec J J. Improving winter hardiness in nondormant alfalfa germplasm[J]. Crop science, 2005, 45: 60-65.

[6] Lauriault L M, Kirksey R E, VanLeeuwen D M. Performance of perennial cool-season forage grasses in diverse soil moisture environments, southern high plains, USA[J]. Crop Science, 2005, 45:909-915.

[7] Lindsay W B, Aleida H W, Megan H R, et al. Water relations and adaptations to increasing water deficit in three perennial legumes, Medicago sativa, Dorycnium hirsutum and Dorycnium rectum[J]. Plant Soil, 2007, 290:231-243. 
[8] Molden D. Accounting for water use and productivity[M]. Colombo: IWMI, Sri Lanks,1997:16. 